\title{
Integrasi Pengolahan Air Limbah Lindi Hitam dengan COD dan TSS Tinggi dari Proses Pembuatan Bioetanol
}

\author{
Ajeng Arum Sari ${ }^{1}$, Tony Bagaswara Utomo ${ }^{2}$, Yusnita Parmawati ${ }^{1}$, Dena \\ Wulandari ${ }^{3}$, dan Sudarno ${ }^{2}$
}

1Pusat Penelitian Kimia LIPI; e-mail: ajeng.a.sari@lipi.go.id

${ }^{2}$ Departemen Teknik Lingkungan, Universitas Diponegoro

${ }^{3}$ Program Studi Teknik Informatika, Universitas Pamulang

\begin{abstract}
ABSTRAK
Limbah lindi hitam merupakan limbah yang berasal dari proses pretreatment tandan kosong kelapa sawit menjadi bioetanol, dimana sampai saat ini tidak memiliki perhatian yang khusus. Limbah pada konsentrasi tertentu dengan melewati batas yang ditetapkan akan menimbulkan pencemaran dan dapat mempengaruhi kondisi lingkungan. Penelitian ini bertujuan untuk mengidentifikasi karakteristik dari lindi hitam dan juga untuk mengetahui efisiensi pengolahan limbah lindi hitam dengan menggunakan kombinasi dari metode koagulasi - flokulasi, AOPs fenton dan adsorpsi.Penelitian ini menggunakan metode jartest, dengan variabel bebas adalah parameter COD, TSS, dan warna. Pada hasil akhir pengolahan didapatkan efisiensi pada metode koagulasi dengan dosis PAC $30 \mathrm{~g} / \mathrm{L}$ efisiensi penurunan COD sebesar 81,68\%, TSS sebesar 82,38\%, warna sebesar 60,31\%. Pada metode fenton dengan dosis $\mathrm{H}_{2} \mathrm{O}_{2} 100 \mathrm{ml} / \mathrm{L}$ efisiensi penurunan COD sebesar 66,81\%, TSS sebesar 53,91\%, warna sebesar 67,90\%. Dan pada metode adsorpsi dengan karbon aktif 20 g efisiensi penurunan COD sebesar 93,30\%, TSS sebesar 18,36\%, warna sebesar 90,06\%. Dari seluruh kombinasi metode pengolahan tersebut didapatkan efisiensi penurunan COD sebesar 99,47\%, TSS sebesar 92,59\%, warna sebesar 98,14\%.
\end{abstract}

Kata kunci: Lindi Hitam, Koagulasi Flokulasi, AOPs, Fenton, Dekolorisasi

\begin{abstract}
Black Liquor is waste disposal from that comes from the pretreatment process of bioethanol from oil palm empty fruit bunches. Which until now has no special attention. Waste at a certain concentration limits set by passing will cause pollution and can affect environmental conditions. This study aims to identify the characteristics of black liquor and also to determine the efficiency of black liquor waste treatment using a combination of methods of coagulation flocculation, AOPs Fenton and filtration. Jartest method used in this study, the independent variables are the parameters COD, TSS, and color. At the end of the processing results obtained efficiencies in coagulation method with PAC dose of $30 \mathrm{~g} / \mathrm{L}$ of COD removal efficiency of $81.68 \%$, TSS of $82.38 \%$, the color of $60.31 \%$. Reviewed by Fenton method $\mathrm{H} 2 \mathrm{O} 2$ dose of $100 \mathrm{ml} / \mathrm{L}$ of COD removal efficiency of $66.81 \%$, TSS of $53.91 \%$, the color of $67.90 \%$. And the method of adsorption with $20 \mathrm{~g}$ of activated carbon COD removal efficiency of $93.30 \%$, TSS of $18.36 \%$, the color of $90.06 \%$. Of all combined processing method is obtained COD removal efficiency of $99,47 \%$, TSS of $92,59 \%$, and the color of $98,14 \%$.
\end{abstract}

Keywords: Black Liquor, Coagulation, Flocculation, AOPs, Fenton, Decolorization

Citation: Sari, A. A., Utomo, T. B., Parmawati, Y.. Wulandari, D., dan Sudarno (2019). Integrasi Pengolahan Air Limbah Lindi Hitam dengan COD dan TSS Tinggi dari Proses Pembuatan Bioetanol. Jurnal Ilmu Lingkungan, 17(1), 100-106, doi:10.14710/jil.17.1.100-106

\section{Pendahuluan}

Tandan kosong kelapa sawit (tkks) merupakan salah satu limbah padat kelapa sawit yang perlu dieksplorasi penggunaannya. Tkks mengandung selulosa dan hemiselulosa sehingga berpotensi untuk dijadikan bahan baku produksi bioetanol (Suyatno, 2010). Pembuatan bioetanol dari tkks terdiri dari beberapa tahap, yaitu perlakuan awal menggunakan $\mathrm{NaOH}$, sakarifikasifermentasi, dan distilasi (Sari et al., 2017). Proses perlakuan awal ini menghasilkan air limbah yang disebut lindi hitam dalam jumlah yang sangat besar. Karakteristik air limbah lindi hitam ini dapat dilihat di Tabel 1. Tabel ini juga memuat baku mutu air limbah usaha dan/atau kegiatan industri minyak sawit berdasarkan Peraturan Menteri Lingkungan Hidup Republik Indonesia Nomor 5 Tahun 2014 tentang Baku Mutu Air Limbah. Parameter yang diatur adalah chemical oxygen demand (COD), total suspended solids (TSS), warna, dan $\mathrm{pH}$. 
Warna hitam pada air limbah ini disebabkan oleh kandungan senyawa lignin yang mengalami proses degradasi lignoselulosa. $\mathrm{NaOH}$ yang digunakan dalam proses perlakuan awal menjadikan $\mathrm{pH}$ air limbah lindi hitam bersifat basa. Karakteristik limbah lindi hitam terdiri dari komponen organik sebanyak 78\% dan komponen anorganik 22\%. Kandungan lignin di dalam komponen organik mencapai 37,5\% (Sjostrom, 1995). Lindi hitam dapat membahayakan ekosistem akuatik apabila masuk ke perairan tanpa diolah terlebih dahulu (Hewitt et al., 2006).

Tabel 1.Karakteristik Air Limbah Lindi Hitam dari Proses Pembuatan Bioetanol

\begin{tabular}{clccc}
\hline \hline No. & Parameter & Satuan & Hasil Analisa & Baku Mutu \\
\hline 1. & COD & $(\mathrm{mg} / \mathrm{l})$ & 113.750 & 350 \\
2. & TSS & (mg/l) & 306,14 & 250 \\
3. & Warna & Ppm & Hitam/500.000 & - \\
4. & pH & - & 12 & $6-9$
\end{tabular}

Sumber data : PermenLH RI No. 5 Tahun 2014

Beberapa teknologi dapat digunakan untuk pengolahan air limbah lindi hitam, seperti koagulasi-flokulasi, Fenton, dan metode biologi (Sari et al., 2015; Sari et al., 2016; Burhani et al., 2017; Sari et al., 2017). Koagulasi merupakan proses fisika-kimia pencampuran koagulan dalam air limbah melalui sistem pengadukan cepat untuk mencapai sifat homogen. Proses koagulasi berfungsi untuk menetralkan atau mengurangi muatan negatif pada partikel sehingga mengijinkan gaya tarik van der waals untuk mendorong terjadinya agregasi koloid dan zat-zat tersuspensi halus untuk membentuk microfloc. Flokulasi merupakan proses penambahan flokulan sehingga terbentuk flok melalui sistem pengadukan lambat untuk meningkatkan aglomerasi antar partikel yang lemah, sehingga setelah itu partikel mudah diendapkan (Steel et al., 1985). Teknologi Fenton merupakan teknologi yang efektif untuk mengurangi COD dan TSS melalui pembentukan radikal hidkroksil. Radikal ini dihasilkan dari reaksi oksidasi antara hidrogen peroksida dan garam Fe(II) sehingga mempunyai potensial oksidasi yang tinggi (Yulia et al., 2016).Adsorpsi merupakan proses masuknya molekul ke dalam pori-pori karena ketidaksamaan gaya pada permukaan. Proses adsorpsi bergantung pada karakteristik fisik maerial adsorben dan ukuran molekul adsorbat.

Penelitian-penelitian pengolahan air limbah lindi hitam yang telah ada saat ini masih menggunakan teknologi tunggal untuk mengolah air limbah lindi hitam yang sudah diencerkan. Akibatnya, teknologi tersebut tidak dapat diterapkan di air limbah lindi hitam dengan konsentrasi sesungguhnya, dimana konsentrasi COD dan TSS sangat tinggi. Untuk mengatasi permasalahan air limbah lindi hitam, dibutuhkan integrasi pengolahan sehingga diharapkan air limbah lindi hitam yang telah diolah dapat mendekati baku mutu yang disyaratkan oleh pemerintah. Oleh karena itu, penelitian ini bertujuan untuk menyisihkan COD, TSS, dan warna pada air limbah lindi hitam dengan menggunakan integrasi sistem koagulasi-flokulasi, Fenton, dan adsorpsi. Diharapkan konsentrasi COD dan TSS air limbah hasil pengolahan ini dapat mendekati baku mutu COD dan TSS yang dipersyaratkan.

\section{Metodologi \\ 2.1. Bahan dan alat}

Bahan-bahan yang digunakan adalah poly aluminum chloride (PAC) teknis, tawas teknis,

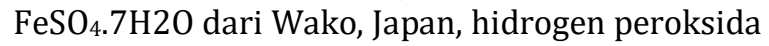
dari Wako, Japan, pasir teknis, dan karbon aktif komersial. Alat yang digunakan pada penelitian ini antara lain gelas beker, gelas ukur, jar test, $\mathrm{pH}$ meter, timbangan digital, reaktor COD dan spektrofotometer.

\subsection{Eksperimen koagulasi-flokulasi}

PAC dan tawas digunakan sebagai koagulan dan flokulan pada proses koagulasi-flokulasi. Variasi PAC yang digunakan adalah 10; 15; 20; 25; dan 30 g/L. Air limbah lindi hitam sebanyak $100 \mathrm{~mL}$ dimasukkan ke dalam gelas beker, kemudian PAC ditambahkan kedalamnya. Larutan tersebut diaduk dengan kecepatan 200 rpm selama 3 menit.pH larutan diatur hingga mencapai 5,5. Tawas sebanyak $15 \mathrm{~g} / \mathrm{L}$ ditambahkan ke dalam larutan, lalu diaduk kembali dengan kecepatan 50 rpm selama 8 menit. Pengendapan selama 24 jam dilakukan untuk memisahkan fase larutan dan lumpur. Sampel berupa fase larutan disentrifugasi pada kecepatan 10000 rpm selama 10 menit, kemudian nilai COD, TSS, dan warnanya diukur.Larutan hasil koagulasi-flokulasi diolah lebih lanjut dengan menggunakan metode Fenton.

\subsection{Eksperimen Fenton}

Reagen Fenton terdiri dari $1,1 \mathrm{~g} / \mathrm{L} \mathrm{FeSO}_{4} .7 \mathrm{H}_{2} \mathrm{O}$ dan variasi hidrogen peroksidasebesar 20; 40; 60; 80; dan $100 \mathrm{ml} / \mathrm{L}$. Larutan yang terdiri dari $50 \mathrm{ml}$ air limbah lindi hitam hasil koagulasi-flokulasi dan reagen Fenton diaduk dengan kecepatan 200 rpm selama 3 menit, kemudian kecepatan pengadukan dikurangi menjadi $50 \mathrm{rpm}$ selama 8 menit. Pengendapan, pemisahan, dan pengukuran parameter dilakukan seperti pada metode di bagian 2.2. Air limbah lindi hitam hasil Fenton diolah lebih lanjut dengan metode adsorpsi.

\subsection{Adsorpsi}

Adsorben yang digunakan adalah pasir aktif berlapiskan $\mathrm{FeCl}_{3}$ dan karbon aktif komersial.Pasir aktif berlapiskan $\mathrm{FeCl}_{3}$ didapatkan dari penelitian sebelumnya (Barlianti et al., 2017). Kombinasi pasir dan karbon aktif dalam satuan 
gram sebagai berikut: 20:0; 17,5:2,5; 15:5; 12,5:7,5; 10:10; dan 0:20. Proses adsorpsi dilakukan dengan mencampur $50 \mathrm{ml}$ air limbah lindi hitam hasil proses Fenton dan kombinasi adsorben. Larutan tersebut diaduk dengan kecepatan $150 \mathrm{rpm}$ selama 6 jam.Pemisahan larutan dan endapannya dilakukan dengan sentrifugasi seperti pada metode di bagian 2.2 , kemudian nilai COD, TSS, dan warnanya diukur.

\subsection{Analisa COD, TSS, dan warna}

Pengukuran konsentrasi COD, TSS, dan warna dilakukan pada air limbah lindi hitam sebelum diolah, setelah proses koagulasi-flokulasi, Fenton, dan adsorpsi. Analisa COD dilakukan berdasarkan SNI 06-6989.2-2009. Analisa TSS dilakukan berdasarkan SNI 06-6989.3-2004. Analisa warna dilakukan berdasarkan metode penelitian dari Sari et al. (2015).Sebagai kontrol, konsentrasi warna air limbah lindi hitam sebelum pengolahan diasumsikan sebesar 500.000 ppm.

Analisa untuk warna dilakukan dengan menggunakan UV-Vis spektrofotometer pada panjang gelombang $655 \mathrm{~nm}$.Analisa TSS dilakukan dengan metode berat kering di dalam oven pada suhu $105^{\circ} \mathrm{C}$ selama 2 jam. Analisa COD dilakukan dengan menggunakan reagen pereaksi COD yang terdiri dari kalium bikromat dan larutan asam sulfat yang sudah dicampur dengan $\mathrm{Ag}_{2} \mathrm{SO}_{4}$ dan dipanaskan pada reaktor COD $148{ }^{\circ} \mathrm{C}$ selama 2 jam (Clesceri et al., 1998). Pengukuran COD dilakukan dengan menggunakan UV-Vis spektrofotometer dengan panjang gelombang 620 nm.

\section{Hasil dan Pembahasan}

\subsection{Pengolahan air limbah lindi hitam dengan} metode koagulasi-flokulasi

Tahap pertama dari sistem integrasi pengolahan air limbah lindi hitam ini adalah koagulasi-flokulasi.Koagulasi-flokulasi dipilih sebagai pengolahan primer air limbah lindi hitam karena beberapa penelitian sebelumnya menunjukkan bahwa metode konvensional ini efektif untuk menyisihkan COD dan warna lindi hitam dari industri pulp and paper. Koagulan berupa PAC divariasikan mulai dari $15 \mathrm{~g} / \mathrm{L}$ hingga 30 g/L. Floakulan berupa tawasdengan konsentrasi $15 \mathrm{~g} / \mathrm{L}$.

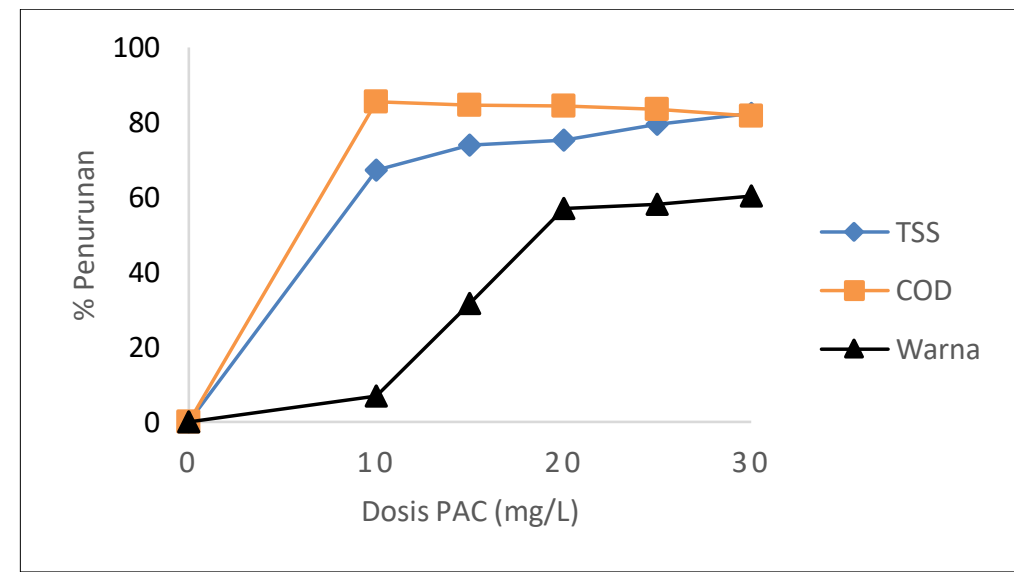

Gambar 1. Penyisihan COD, TSS, dan warna pada air limbah lindi hitam dengan metode koagulasi-flokulasi

Gambar 1 menunjukkan bahwa COD dapat disisihkan pada kisaran $80 \%$ untuk semua dosis PAC. Penyisihan tertinggi parameter COD sebesar 85,49\% didapat pada penggunaan PAC $10 \mathrm{~g} / \mathrm{L}$ dan tawas15 g/L. Penyisihan TSS menunjukkan nilai yang bervariasi.Semakin besar konsentrasi PAC yang digunakan maka penurunan nilai TSS dan warna semakin besar. Penyisihan TSS memiliki rentang sebesar 67,32-82,38\%. Penyisihan TSS tertinggi sebesar $82,38 \%$ didapat dari penggunaan PAC $30 \mathrm{~g} / \mathrm{L}$ dan tawas15 g/L. Nilai penyisihan warna tertinggi sebesar 60,31\% diperoleh dari penggunaan PAC $30 \mathrm{~g} / \mathrm{L}$ dan tawas15 g/L.

COD dari air limbah paper machine, hasil ekstraksi alkali, dan proses bleaching dapat disisihkan sebesar 96, 50, dan 20\%. Proses ini juga mampu menyisihkan warna pada air limbah dari proses bleaching sebesar 80\% (Dilek \& Gokcay, 1994). Besi klorida mampu menyisihkan total karbon dan warna pada air limbah mechanical pulping sebesar masing-masing 88 dan 97\% (Stephenson \& Duff, 1996). Air limbah ini mempunyai konsentrasi COD awal sebesar 25707930 ppm. Garg et al. (2010) menguji kemampuan tawas untuk menyisihkan COD dan warna pada lindi hitam dengan proses koagulasi. COD awal air limbah ini adalah 7000 ppm. Tawas sebesar $5 \mathrm{~g} / \mathrm{L}$ mampu menyisihkan COD dan warna sebesar masing-masing 63 dan 90\%.

Proses koagulasi menyebabkan terjadinya penurunan atau penetralan muatan listrik pada partikel-partikel tersuspensi atau zeta-potentialnya. Muatan-muatan listrik yang sama pada partikel-partikel kecil dalam air menyebabkan partikel-partikel tersebut saling menolak sehingga 
membuat partikel-partikel koloid kecil terpisah satu sama lain dan menjaganya tetap berada dalam suspensi (Ebeling \& Sarah, 2004). Pengadukan lambat menimbulkan gaya tarikmenarik antar partikel koloid yang semakin besar dan lebih mendominan dibandingkan

gaya tolaknya sehingga menghasilkan kontak dan tumbukan antar partikel koloid lebih banyak dan lebih sering terjadi (Tchobanoglous et al., 2003). Akibatnya, nilai COD akan menurun.

TSS merupakan flok yang terbentuk karena adanya penetralan muatan negatif dari koloid penyebab kekeruhan air dengan muatan positif dari koagulan PAC (Budiman et al., 2008). PAC dapat memperlambat laju presipitasi hidroksida pada pengolahan air limbah, dipertahankan untuk waktu lama, dan lebih kuat dalam menyerap air limbah pada permukaan (Sanghi \& Bhattacharya, 2005). Penyisihan TSS pada proses koagulasiflokulasi sangat diperlukan untuk meringankan pengolahan selanjutnya. Semakin banyaknya kation yang dihasilkan dari koagulan, maka semakin banyak pula partikel koloid dalam air yang dinetralkan dan membentuk flok, sehingga nilai penyisihan TSS akan meningkat.

$$
\begin{aligned}
& \text { Tawas : } \mathrm{Al}_{2}\left(\mathrm{SO}_{4}\right)_{3} \cdot 18 \mathrm{H}_{2} \mathrm{O} \rightarrow 2 \mathrm{Al}^{3+}+3 \mathrm{SO}_{4}{ }^{2-}+18 \mathrm{H}_{2} \mathrm{O} \rightarrow 2 \mathrm{Al}(\mathrm{OH})_{3}+6 \mathrm{H}^{+}+3 \mathrm{SO}_{4}^{2-}+12 \mathrm{H}_{2} \mathrm{O} \\
& \text { PAC }: \mathrm{Al}_{2}(\mathrm{OH})_{3} \cdot \mathrm{Cl}_{3} \rightarrow \mathrm{Al}_{2}(\mathrm{OH})_{3}{ }^{3+}+3 \mathrm{Cl}^{-}+3 \mathrm{H}_{2} \mathrm{O} \rightarrow 2 \mathrm{Al}(\mathrm{OH})_{3}+3 \mathrm{H}^{+}+3 \mathrm{Cl}^{-}
\end{aligned}
$$

Reaksi kimia diatas adalah reaksi hidrolisis antara koagulan dan diikuti dengan pembentukan logam hidroksida flok serta ion hidrogen. Ion hidrogen akan bereaksi dengan alkalinitas air dan dalam proses sehingga menurunkan $\mathrm{pH}$ air (Burhani \& Sari, 2015).Penurunan warna disebabkan oleh adanya pembentukan muatan positif hidroksida akibat reaksi hidrolisis oksida dengan air sehingga yang menyerap zat organik penyebab warna (zat asam humat dan fulvat) sebelum hidroksida mengendap (Hendricks, 2005).

\subsection{Pengolahan air limbah lindi hitam dengan menggunakan metode Fenton}

Setelah diolah dengan proses koagulasiflokulasi, air limbah lindi hitam diolah dengan menggunakan proses Fenton, salah satu dari teknologi Advanced Oxidation Processes (AOPs).AOPs adalah teknologi pengembangan oksidasi konvensional yang bertujuan meningkatkan kemampuan oksidasi dari oksidator biasa.AOPs dihasilkan dari penggabungan oksidator-oksidator maupun penggunaan sinar UV sehingga dihasilkan hidroksil radikal $(\mathrm{OH} \bullet)$ yang memiliki potensial redoks besar. Hidroksil radikal merupakan oksidator kuat setelah gas Flourine dengan potensial redoks sebesar 2,8 V (Krisma, 2008).

Penggunaan reagen Fenton di dalam proses dibuat atas perbandingan berat antara hidrogen peroksida dan garam besi [II].Garam besi [II] yang diperlukan adalah seperduapuluh sampai seperlima bagian berat hidrogen peroksida (Watts, 1998). Variasi yang digunakan adalah penggunaan hidrogen peroksida dari 20 hingga $100 \mathrm{ml}$ untuk dosis $\mathrm{FeSO}_{4} \cdot 7 \mathrm{H}_{2} 0$ sebesar 1,1 g/L. Gambar 2 menunjukkan penyisihan COD, TSS, dan warna pada air limbah lindi hitam dengan menggunakan metode Fenton.

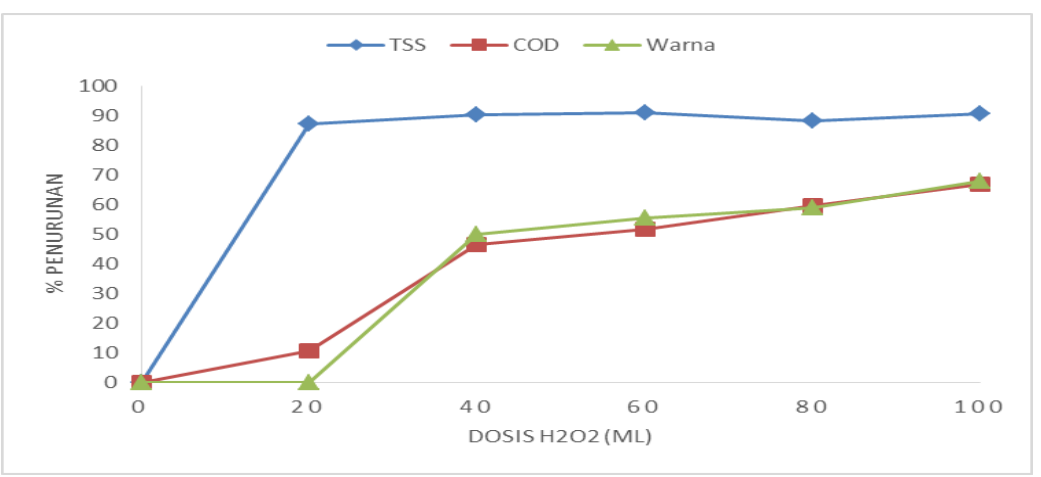

Gambar 2.Penyisihan COD, TSS dan warna pada air limbah lindi hitam hasil koagulasi-flokulasi dengan metode Fenton 
Hidrogen peroksida merupakan reagen yang dapat dikonversi menjadi radikal hidroksil $\left(\mathrm{HO}^{\bullet}\right)$ yang kekuatan potensial oksidasinya lebih besar dari $\mathrm{H}_{2} \mathrm{O}_{2}$ itu sendiri. Penggunaan $\mathrm{H}_{2} \mathrm{O}_{2}$ disertai dengan garam besi $\left(\mathrm{Fe}^{2+}\right)$ disebut proses Fenton, dapat menjadi sumber radikal hidroksil yang baik untuk digunakan dalam pengolahan air tercemar kontaminan organik (Elfiana, 2013).Senyawa organik pada polutan dapat dipecah menjadi senyawa sederhana melalui reaksi radikal tersebut.

Gambar 2 menunjukkan bahwa peningkatan konsenstrasi hidrogen peroksida mengakibatkan peningkatan nilai penyisihan COD. Kemampuan hidrogen perosida dalam menyisihkan COD, TSS, dan warna tidak sama. Penyisihan COD tertinggi yaitu 66,81\% didapatkan pada penggunaan hidrogen peroksida sebesar $100 \mathrm{ml} / \mathrm{L}$. Akan tetapi, konsentrasi hidrogen peroksida $20 \mathrm{~mL} / \mathrm{L}$ mempunyai efektivitas yang tidak berbeda jauh dengan konsentrasi hidrogen peroksida sebesar $100 \mathrm{~mL} / \mathrm{L}$ dalam menyisihkan TSS, berkisar antara 83\%. Berdasarkan penelitian Isyuniarto (2006), penurunan partikulat TSS terjadi karena radikal hidroksil langsung bertumbukan dengan zat organik dalam air limbah sehingga dapat mengoksidasi parameter pencemar dalam air limbah. Untuk penyisihan warna, semakin besar dosis Fenton yang digunakan maka akan berbanding lurus dengan penurunan warna yang terjadi pada limbah lindi hitam. Nilai penyisihan warna tertinggi sebesar $67,90 \%$ didapatkan pada penggunaan hidrogen peroksida sebesar 100 $\mathrm{ml} / \mathrm{L}$.

\subsection{Efisiensi penyisihan COD dan TSS dengan metode adsorpsi}

Air limbah lindi hitam yang diolah dengan metode Fenton dilanjutkan dengan metode adsorpsi. Variasi yang digunakan adalah kombinasi penggunaan pasir aktif berlapiskan Fe dan karbon aktif komersial (Tabel 2).

Hasil adsorpsi menunjukkan bahwa penggunaan karbon aktif saja lebih efektif untuk menyisihkan COD, TSS, dan warna daripada kombinasi dua adsorben atau adsorben pasir aktif berlapiskan $\mathrm{FeCl}_{3}$ saja. Akan tetapi, penyisihan TSS pada proses ini kurang dari 20\%. Kadar COD dalam air limbah akan diserap oleh karbon aktif karena karbon aktif mempunyai suatu gaya gabung dengan bahan organik sehingga mampu menyisihkan bahan kontaminan organik dari air limbah.Karbon aktif merupakan material terkarbonisasi yang sudah diaktifkan sehingga pori-porinya terbuka dan permukaannya bertambah luas (sekitar 300-2000 $\mathrm{m}^{2} / \mathrm{g}$ ).Permukaan karbon aktif yang luas ini mengakibatkan daya adsorpsinya terhadap cairan dan gas makin tinggi.Molekul yang berukuran kecil mudah terjerap pada pori-pori karbon aktif (Weber, 1981 dalam Rosyida, 2011).

Tabel 2 Penyisihan COD dan TSS Limbah Lindi Hitam dengan Metode Adsorbsi

\begin{tabular}{ccccc}
\hline \hline Pasir & Karbon & \multicolumn{2}{c}{ Efisensi Penyisihan (\%) } \\
\cline { 3 - 5 } (g) & Aktif (g) & COD & TSS & Warna \\
\hline 20 & 0 & 0,55 & 0 & 12,5 \\
17,5 & 2,5 & 26,97 & 0 & 25,02 \\
15 & 5 & 70,83 & 4,54 & 87,28 \\
12,5 & 7,5 & 76,70 & 6,12 & 87,28 \\
10 & 10 & 77,71 & 15,12 & 89,63 \\
0 & 20 & 93,30 & 18,36 & 90,06 \\
\hline
\end{tabular}

Menurut Weber (1981) dalam Rosyida (2011), salah satu faktor yang mempengaruhi adsorpsi adalah luas permukaan adsorben sebagai tempat adsorpsi. Semakin besar luas permukaan adsorben maka semakin besar pula adsorpsi yang dilakukan. Menurut Sihombing (2007) tahap dasar dari proses adsorpsi terdiri dari zat yang terjerap pada bagian luar, bergerak menuju pori dan terjerap ke dinding dalam. Bahan organik yang terjerap pada proses adsorpsi membuat konsentrasi TSS akan berkurang karena TSS terdiri dari bahan organik dan inorganik.

Hasil seluruh pengolahan dari limbah lindi hitam awal hingga hasil akhir setelah adsorpsi dapat dilihat pada Tabel 3.

Tabel 3.Efisiensi Pengolahan Air Limbah Lindi Hitam pada Tiap Metode

\begin{tabular}{lcccccc}
\hline \hline & COD (mg/L) & Penyisihan (\%) & TSS (mg/L) & Penyisihan (\%) & Warna (ppm) & Penyisihan (\%) \\
\hline $\begin{array}{l}\text { Sebelum } \\
\text { pengolahan }\end{array}$ & 113.750 & - & 306 & - & 500.000 & - \\
$\begin{array}{l}\text { Koagulasi- } \\
\text { Flokulasi }\end{array}$ & 18.833 & 83,44 & 62 & 79,47 & 209.450 & 58,11 \\
Fenton & 9.083 & 51,77 & 27 & 55,79 & 93.475 & 55,37 \\
Adsorpsi & 608 & 90,47 & 22 & 18,36 & $9290 /$ bening & 90,06 \\
\hline
\end{tabular}

Berdasarkan Tabel 3, seluruh tahapan pengolahan mulai dari koagulasi, Fenton, dan adsorpsi mampu menyisihkan COD, TSS, dan warna dengan hasil akhir konsentrasi COD sebesar $608 \mathrm{mg} / \mathrm{L}$, TSS sebesar $22 \mathrm{mg} / \mathrm{L}$ dan warna 9290 ppm bening/tidak berwarna. Jika dibandingkan dengan baku mutu Peraturan Menteri Lingkungan Hidup Republik Indonesia No. 5 Tahun 2014, nilai TSS sudah memenuhi 
baku mutu, sedangkan nilai COD belum memenuhi baku mutu yang ditetapkan.

\section{Kesimpulan}

Proses perlakuan awal pembuatan bioetanol dari tandan kosong kelapa sawit menghasilkan air limbah lindi hitam dengan konsentrasi COD dan TSS sebesar $113.750 \mathrm{mg} / \mathrm{L}$ dan 306,14 mg/L serta berwarna hitam. Air limbah ini diolah dengan menggunakan sistem integrase yang terdiri koagulasi-flokulasi, Fenton, dan adsorpsi. Hasil penelitian menunjukkan bahwa dosis optimum untuk pengolahan lindi hitam adalah koagulan PAC 30g/L, flokulan tawas $15 \mathrm{~g} / \mathrm{L}$, reagen yang terdiri dari $\mathrm{FeSO}_{4}$ 1,1 g/L dan $100 \mathrm{ml}$ hidrogen peroksida serta adsroben berupa karbon aktif sebanyak 20 g. Hasil akhir sistem pengolahan ini adalah nilai COD dan TSS sebesar $608,33 \mathrm{mg} / \mathrm{L}$ dan 22,68 mg/L serta bening. Nilai TSS telah memenuhi baku mutu menurut Peraturan Menteri Lingkungan Hidup Republik Indonesia Nomor 5 Tahun 2014. Teknologi tambahan seperti metode biologi tetap diperlukan untuk menyisihkan sisa nilai COD pada air limbah lindi hitam.

\section{Ucapan Terimakasih}

Penelitian ini didanai oleh Program Insentif Riset Sistem Inovasi Nasional (Insinas) Tahun Anggaran 2017-2018. Penulis mengucapkan terima kasih kepada Novita Ariani yang telah membantu dalam penelitian ini.

\section{DAFTAR PUSTAKA}

Aziz, H.A.,S.S.A. Amr. 2012.New treatment of stabilized leachate by ozone/Fenton in the advanced oxidation process, School of Civil Engineering, Engineering Campus, Universiti Sains Malaysia, Penang, Malaysia.

Barlianti, V., E. Triwahyuni, J. Waluyo, A.A. Sari. 2017Decolorization of black liquor from bioethanol G2 production using iron oxide coating sands, AIP Conference Proceedings 1803, 020003.

Budiman, A., C. Wahyudi, W. Irawati, H. Hindarso. 2008 Kinerja koagulan poly aluminium chloride (pac) dalam penjernihan air sungai kalimas surabaya menjadi air bersih, Universitas Katolik Widya Mandala, Surabaya.

Burhani, D., A.A. Sari. 2015.Water recovery of black liquor wastewater in bioethanol process from oil palm empty fruit bunchby coagulation and flocculation method, Research Center for Chemistry, Indonesian Institute of Sciences, Kawasan Puspiptek Serpong, Tangerang Selatan, Indonesia.

Burhani, D., A. Winarni, A.A. Sari. 2017. Effect of coagulant/flocculant dosage and $\mathrm{pH}$ to water recovery of black liquor wastewater in bioethanol production from oil palm empty fruit bunch using response surface methodology, AIP Conference Proceedings, 1803, 020004.

Clesceri, L. S., A.E. Greenberg, A.D. Eaton. 1998. Standard methods for the examination of water and wastewater. $20^{\text {th }}$ ed. American Public Health Association, Washington, ISBN 0875532357.
Dilek, F. B., C.F. Gokcay. 1994. Treatment of effluents from hemp-based pulp and paper industry: waste characterization and physiochemical treatability, Water Sci. Technol, 29, 161-163.

Ebeling, J. M., R.O.Sarah. 2004 Application of Chemical Coagulation Aids for the Removal of Suspended Solids (TSS) and Phosphorus from the Microscreen Effluent Discharge of an Intensive Recirculating Aquaculture System, North American Journal of Aquaculture, 66, 198-207.

Elfiana. 2013.Penurunan Konsentrasi COD Air Limbah Domestik dengan Reagen Fenton secara Batch, Politeknik Negeri Lhoksumawe, Lhoksumawe.

Garg, A., I.M. Mishra, S. Chand. 2010.Effectiveness of coagulation and acid precipitation processes for the pre-treatment of diluted black liquor, Journal of Hazardous Materials, 180, 158-164.

Hendricks, D. W. 2005. Water Treatment Unit Processes: Physical and Chemical, Taylor and Francis Groups, USA.

Hewitt, L. M., J.L. Parrott,M.E. McMaster. 2006. A decade of research on the environmental impacts of pulp and paper mill effluents in Canada: sources and characteristics of bioactive substances, Journal of Toxicology and Environmental Health, Part B, 9, 341-356.

Isyuniarto.2006. Aplikasi Ozon Hasil Lucutan Plasma untuk Menurunkan nilai pH, COD, BOD, dan Jumlah Bakteri Limbah Cair Rumah Sakit, Batan, Serpong.

Krisma, A. 2008. Penyisihan Besi Dan Zat Organik Dari Air Tanah Menggunakan Ozon (Aop), ITB, Bandung.

Rosyida, A. 2011. Bottom ash Limbah Batubara sebagaiMedia Filter yang Efektif pada Pengolahan Limbah Cair Tekstil, Jurnal Rekayasa Proses, 5, No. 2.

Sanghi, R. B. Bhattacharya. 2005. Comparative Evaluation of Natural Polyelectrolytes Psllium and Chitosan as Coagulant Aids for Decolourization of Dte Solutions, Water Quality Res. J, 40, 97-101.

Sari, A. A., H.H. Kurniawan, M. Nurdin, H. Abimanyu.2014. Decolorization of black liquor wastewater generated from bioethanol process by using oil palm empty fruit bunches, Research Center for Chemistry, Indonesian Institute of Sciences, Kawasan Puspiptek Serpong, Tangerang Selatan, Indonesia.

Sari, A. A., H.H. Kurniawan, M. Nurdin, I.F. Anggraini. 2015. A combined wastewater treatment for degradation of black liquor from bioethanol process, Research Center for Chemistry, Indonesian Institute of Sciences, Kawasan Puspiptek Serpong, Tangerang Selatan, Indonesia.

Sari, A. A., F. Amriani, I.F. Anggraini. 2016. Performance of Ceriporiopsis sp. in the Treatment of Black Liquor Wastewater, Jurnal Teknologi Lingkungan, $17,58-65$.

Sari, A. A., N. Ariani, Muryanto, T.B. Utomo, Sudarno. 2017. Potential of oil palm empty fruit bunches for bioethanol production and application of chemical methods in bioethanol wastewater treatment : OPEFB for bioethanol and its wastewater treatment, 2nd International Conference Sustainable and Renewable Energy Engineering (ICSREE), Hiroshima, 10-12 Mei 2017.

Sihombing, J. B. F. 2007. Penggunaan Media Filtran Dalam Upaya Mengurangi Beban Cemaran Limbah 
Cair Industri Kecil Tapioka, Departemen Teknologi Industri Pertanian Fakultas Teknologi Pertanian Institut Pertanian, Bogor.

Sjostrom, E. 1995.Kimia Kayu: Dasar - dasar dan Penggunaan. Jilid 2, Universitas Gajah Mada Press, Yogyakarta.

Steel, R.J., J .Gjelberg, W. Helland-Hansen, K.L. Kleinspehn, A. Nottvedt, M. Rye-Larsen. 1985. The Tertiary strike-slip basins and orogenic belt of Spitsbergen. In: Biddle, K.T., Christie-Blick, N. (Eds.), Strike-slip Deformation, Basin Formation and Sedimentation, Special Publication, 37, 339359.

Stephenson, R. J., S.J.B Duff. 1996.Coagulation and precipitation of a mechanical pulping effluent-I. Removal carbon, colour and turbidity, Water Research, 30, 781-792.

Suyatno.2010. Proses Produksi Bioetanol dari Tandan Kosong Kelapa Sawit dengan Hot-CompressedWater, Seminar Rekayasa Kimia dan Proses, Serpong, 4-5 Agustus 2010.

Tchobanoglous. 2003. Wastewater Engineering Treatment and Reuse, McGraw Hill Company, New York.
Vedrenne, M., R. Vasquez-Medrano, D. PratoGarcia, B.A. Frontana-Uribe, J.G. Ibanez. 2012. Characterization and detoxification of a mature landfill leachate using a combined coagulation-flocculation/photo Fenton treatment, J. Hazard Mater, 205-206, 208215.

Vedrenne, M., R.V. Medrano, D.P. Garcia, B.A.F. Uribe, J.G. Ibanez. 2012. Characterization and detoxification of a mature landfill leachate using a combined coagulation-flocculation/photo Fenton treatment, Department of Chemistry \& Chemical Engineering, Universidad Iberoamericana, Mexico City, Prolongación Paseo de la Reforma 880, Col. Lomas de Santa Fe, Mexico.

Watts, J. R. 1998. Hazardous Waste: Sources, Pathways, Recycles, John Willey \& Sons Inc, New York.

Yulia, R., H. Melina, Adisalamun, Darmadi. 2016. Aplikasi Metode Advance Oxidation Process (AOP) Fenton pada Pengolahan Limbah Cair Pabrik Kelapa Sawit, Jurnal Rekayasa Kimia dan Lingkungan, $11,1-9$. 